\title{
Grouting applications of grout curtains in Cindere dam and hydroelectric power plant
}

\author{
Devrim ALKAYA* and Burak YEŞiL \\ Department of Civil Engineering, Faculty of Engineering, Pamukkale University, Denizli, Turkey. \\ Accepted 9 May, 2011
}

\begin{abstract}
Grouting is one of the most popular methods used to control water leaking in fill dam constructions. Geological and geotechnical properties of the rock/soil to be grouted are important parameters influencing the design of the grouting. In this study, geotechnical properties of Cindere dam's base rock and the grouting procedure have been investigating view of suitability to grouting. Detailed investigations of the foundation injection applications made into the main rock, the reasons and types of application are made. The materials used in grouting and the grouting pressures are investigated at site and the obtained results are presented. The improvement study and application type is evaluated and background information on different applications of grouting is presented.
\end{abstract}

Key words: Grouting dam, Cindere dam, imperviousness.

\section{INTRODUCTION}

In the construction project of Cindere dam and hydroelectric power plant (HEPP), the dam embankment was designed as "roller compacted hardfill $(\mathrm{RCH})$ ". The embankment fill, following the removal of the alluvium that reached a $36 \mathrm{~m}$ thickness, was directly placed on the Paleozoic schists which are the bedrock.

During the construction of dams, it is necessary to take various precautions in order to enable the impermeability and stability of the bedrock. Among these precautions, grouting through the dam axis, by excavating until the bedrock is reached, is most common one. The grouting is defined as the filling of the fluid material by applying pressure, to the structural and lithological defects or to the voids between soil and structure, generally caused by the drilled whole (Kutzner, 1996). Within a certain time period, the fluid material becomes gel or solidified. The main aim of the grouting is to form more competent and less permeable parent soil or rock (Tosun, 2000). In the study, the foundation grouting applied on the bedrock, the application purposes, and the application methods were examined comprehensively. The rehabilitation works applied and its method of implementation was

*Corresponding author. E-mail: devrimalkaya@hotmail.com. Tel: +90258 2963409. Fax: +902582963382. investigated; and knowledge regarding different applications were attempted to be formed.

\section{GENERAL INFORMATION ON CINDERE DAM}

The Cindere dam and HEPP are built on the Büyük Menderes River located on $5 \mathrm{~km}$ northwest of Güney District belonging to Denizli Province in Turkey. The dam is irrigation (4600 ha) and energy ( $88 \mathrm{GWh} /$ year) purposed. RCC (roller compacted concrete) was previously used in the constructions of Karakaya dam, Atatürk dam, Sır dam, Berke dam, Kürtün, and Çine dams. The construction of a dam totally by using $\mathrm{RCH}$ in Turkey, on the other hand, is first being actualized in Cindere dam. The technical information about the dam is presented in Table 1.

Geological and geotechnical characteristics of the dam foundation

In the studies conducted in the dam site, 25 mechanical drills, with a total depth of $1150 \mathrm{~m}$, were abridged. In the final project phase, 9 additional mechanical drills were abridged through the dam axis. Water pressure tests (WPT) were implemented during the drilling procedure in 
Table 1. Technical data on the dam (DSI, 1999).

\begin{tabular}{lclc}
\hline Type & Roller compacted hardfill (RCH) & Maximum water level & $\mathbf{2 6 7 . 7 0 ~} \mathbf{~ m}$ \\
\hline Crest elevation & $272.00 \mathrm{~m}$ & Annual mean water & $839.98 \mathrm{hm}^{3} / \mathrm{yll}$ \\
Crest length & $280.58 \mathrm{~m}$ & Total area of reservoir & $84.27 \mathrm{hm}^{3}$ \\
Height from the thalweg & $72.00 \mathrm{~m}$ & Regulation ratio & $98.3 \%$ \\
Height from the foundation & $107.00 \mathrm{~m}$ & Total installed power & $9.31 \mathrm{MW}$ \\
Total filling volume & $1.50 \mathrm{hm}^{3}$ & Project decline & $50.50 \mathrm{~m}$ \\
Derivation tunnel & $5.00 \mathrm{~m}$ diameter circular concrete & Project flow rate & $70.20 \mathrm{~m}^{3} / \mathrm{sn}$ \\
Reservoir area & $768.42 \mathrm{~m}$ in right coast & & \\
\hline
\end{tabular}

the regions which the rock properties do permit.

The permeability and mechanical and physical properties of the mica schists and lime schists which are bedrock, the thickness and permeability of the talus and alluvium, the relation of the underground water depth and river depth were investigated.

Following the excavations in the dam embankment, according to the data belonging to foundation exploratory drills, mean value of $35 \mathrm{~m}$ alluvium exists in the dam embankment.

After the excavations, mean value of alluvium were removed on the thalweg; and bedrock schists (micha schists, lime schists, and graphite schists) were broken at $165.00 \mathrm{~m}$ altitude and at 167.00 to $168.00 \mathrm{~m}$ altitude in right coast side regions.

Micha schists stood out with their gray- deep gray tones. Graphite planes, in forms of black and grayish bands, were observed between micha schists in some sections. The schists were generally slightly decomposed, faulted and multi crackled, and had weakmedium strength. The unit, having an average of $30 \mathrm{~m}$ wide yellowish level in in the foundation base excavation and left slope, confirms the surface observations with its considerably decomposed quality and multi faulted structure.

The positioning of schistosity is generally NW-SE (N NW - S SW), and NE-SW (N NE - S SW) directional; and the mean value of lamination inclination angle is between $30-40^{\circ}$ but it can reach up to $45^{\circ}$ in some levels.

The joint sets generally form shears with schistosity planes in the site; and appear to be sensitive against wedged and planar slips. The joints are nearly E - W directional in the site, and have an inclination close to the vertical axis. The mean inclination angle is $70^{\circ}$ whereas the maximum inclination angle is $79^{\circ}$.

Calcite and quartzite veins, which are parallel to the schistosity planes- also partly irregular- and have different thickness values, are encountered inside the schists. The thickness values of these veins range between $5 \mathrm{~cm}-2 \mathrm{~m}$.

The engineering classification of the schists, forming the basis of the dam embankment, was implemented, in relation with their sample characteristics, according to
RMR system (Bieniawski, 1989); which is approved internationally by the researchers. Within this scope, the natural conditions of the rocks and the circumstances following the water holding were evaluated separately. Mica schist, according to the classification parameters determined empirically, has the quality of a "good rock"; and the qualitative representations are as below parameters (Anonymous, 1979; ASTM, 1980):

Cohesion (c): 300 to $400 \mathrm{kPa}$

Angle of internal friction $(\phi): 35^{\circ}-45^{\circ}$

Elasticity module (E): $26 \mathrm{GPa}$

The graphite is the weakest among the schist masses. Nonetheless, this unit has no consistency inside the mass and, therefore, has no effect on the total engineering behavior of the mass. In this sense, the weakest member of the schists, in relation with mass, is the mica schist.

Following the filling of the dam reservoir, only the water effect on the mass would change for the schists. Such schists have the quality of being "medium rock" according to the classification parameters; and the values below were obtained (Anon, 1979; ASTM, 1980):

Cohesion (c): $200-300 \mathrm{kPa}$

Angle of internal friction $(\phi): 25$ to $35^{\circ}$

Elasticity module (E): $8.9 \mathrm{GPa}$

The underground water level, determined according to the basic exploratory drills and the data that underground water feeds Menderes River (DSI, 1999) were confirmed by the existing situation encountered following the excavations.

During the dam embankment excavations, water flow from the base, inside the alluvium accumulated in the river mouth side outside the excavation site, and especially from the slopes to the cut-off excavation hole was encountered. The underground water coming from the schists in the right coast was more in amount than the left coast.

According to the results of the chemical analysis on the water that emerged from the right coast, it was observed that the water was strongly, weakly, and very strongly 
effective according to the sulfate, magnesium, and free $\mathrm{CO}_{2}$, respectively. In order to prevent the contact of these waters with $\mathrm{RCH}$, the thickness value of $50 \mathrm{~cm}$ thick $\mathrm{CO}_{2}$ concrete, poured between $\mathrm{RCH}$ and slopes, was increased to $100 \mathrm{~cm}$, starting from the level of $170.50 \mathrm{~m}$ only in the right coast; and the water damage on $\mathrm{RCH}$ was restrained by increasing the infiltration length of water (DSI, 1999).

\section{GROUTING APPLICATIONS}

Grout curtain, and grout curtain connection, and contact and consolidation application projects, implemented within the construction of Cindere dam, were designed according to the principles in "drilling and grouting technical specification (DSi, 1993)", prepared by General Directorate of State Hydraulic Works (DSi), Geotechnical Services and Groundwater Department, and as a "Special Technical Project"; by also considering the geotechnical characteristics of dam site. The grouting applications consist of:

(i) Grout curtains and curtain connections, implemented from the grouting galleries and derivation tunnels, with the purpose of preventing the possible water leakages in the limestone, schist, and micha schists that form the base of the embankment, after the total removal of alluvium under the embankment,

(ii) Contact groutings, implemented in the grouting galleries at the level 220.50 to $272.00 \mathrm{~m}$, with the purpose of filling the spacing between the coating concrete and bedrock,

(iii) Consolidation groutings implemented with the purpose of strengthening the bedrock.

For the grout curtain and grout curtain connection applications, 24 $\mathrm{m}$ ano cast system decreasing space method was implemented. Nonetheless, according to the intake condition, the ano casts were decided to be bought in dimensions of 12 or $6 \mathrm{~m}$ with the approval of the management.

$12 \mathrm{~m}$ ano cast system and decreasing space method and $24 \mathrm{~m}$ ano cast system and decreasing space method was used, respectively, for contact and consolidation groutings. It was considered that should be grouting procedure should be finalized in at least two ano casts during the contact groutings in order to continue with the consolidation grouting.

\section{Drilling method}

The grouting holes were abridged with rotary drilling method. In the grout curtains, the holes of ano heads $(24.00 \mathrm{~m})$ were abridged with cores whereas the interim drills were abridged without using core drilling. The grout curtain connections were abridged without using cores.

The data regarding the geotechnical features of these holes were obtained from the core drills abridged in the galleries on the slopes. In the interval holes of grout curtains and curtain connections, the hydraulic pressure tests were additionally implemented in line with the directives of management.

During the drilling procedure, hydraulic pressure tests, from top to bottom, on all the holes of $24 \mathrm{~m}$ grout curtain ano heads. This rule also applied to the grout curtain connection holes.

In the hydraulic water tests, pressure was applied in increasing and decreasing stages on the ano head holes whereas single stage pressure was applied on the interim holes with the approval of the management.

\section{Materials used in grouting}

\section{Sulfate-resistant cement}

In the sulfate-resistant cement, compatible with the Turkish Standarts (TS) 10157 (1992), tricalcium aluminate amount did not exceed 3.5\% (Batı Söke Çim, 2002).

\section{Normal Portland cement}

Portland cement, compatible with the PÇ-325 in TS 197-1 (200), was used in all the grouting applications except in the regions where sulfate-resistant cement would be used. The specific surface of this cement should be minimum $2400 \mathrm{~cm} 2 / \mathrm{g}$; and the cement should leave maximum 1\% relic on the sieve with 200 micron aperture size whereas the relic percentage should be maximum $12 \%$ on the sieve with 90 aperture size. In the sections where the water leakage is substantial but intake is less, cements with higher value of specific surface and more relic amount were used.

\section{Water}

The water used in grouting is clean and clear water having the characteristics of mixing water used in concrete.

\section{Bentonite}

Bentonite was used, during the mixing and grouting, to enable the sensitivity of the mortar, by keeping cement particles and sand suspended, and to minimize the disintegration of water in the cement water mixture. All of the grouts and mortar grouts in the grouting procedure were used by adding bentonite in a ratio between 2 to $5 \%$ of the cement amount (Karakaya, 2002). The specifications of the bentonite used were compatible with the TS 977 (1971)

\section{Sand}

In the grouting stages with more intake, the sand, in ratios of 25 , $50,100,200 \%$ of the cement amount, were added to the grouts. The sand used belonged to the hard and durable stones. The particles were generally circular or cubic, thin or medium sized; and no organic material, sulfate, or clay was contained in the sand. If the total amount of these harmful materials exceeded $5 \%$ in the beginning of the procedure, then the sand was sure to be used after being clarified from these materials by washing.

The 95 and $50 \%$ of this sand used should respectively pass through the Sieves number $16(1.19 \mathrm{~mm}$ aperture size) and 50 (0.297 aperture size) according to their weights. Through the Sieve numbered 200 (74 micron aperture size), on the other hand, not more than $5 \%$ of the sand was observed to be passing. Its weight per unit of volume is more than $2 \mathrm{~g} / \mathrm{cm}^{3}$.

When the organic matter tests, compatible with TS 707 (1980), was applied on the sand, it should not present a color darker than the standard reference color. In order to use sand that does not present a darker color than the standard reference color, 7 and 28 days pressure resistivity values should be minimum $95 \%$ of the resistivity values of the comparison cubes made from standard sand (TS EN 196-1, 2002), at the same conditions. Otherwise, this sand was not used in the grouting procedure. 
Table 2. Mixture ratios of the slurries used in grouting applications.

\begin{tabular}{|c|c|c|c|c|c|c|c|}
\hline \multirow{2}{*}{ Mixture rate (cement/water) } & \multirow{2}{*}{$\begin{array}{c}\text { Cement } \\
(\mathrm{kg})\end{array}$} & \multirow{2}{*}{$\begin{array}{l}\text { Water } \\
\text { (I) }\end{array}$} & \multicolumn{2}{|c|}{ Bentonite } & \multirow{2}{*}{$\begin{array}{l}\text { Sand } \\
(\mathrm{kg})\end{array}$} & \multirow{2}{*}{$\begin{array}{l}\text { Volume } \\
\text { (I) }\end{array}$} & \multirow{2}{*}{$\begin{array}{l}\text { Density } \\
\left(\mathrm{g} / \mathrm{cm}^{3}\right)\end{array}$} \\
\hline & & & $\%$ & $(\mathrm{~kg})$ & & & \\
\hline $1 / 3$ & 50 & 125 & 5 & 2.5 & - & 167.37 & 1.21 \\
\hline 213 & 100 & 110 & 4 & 4 & - & 184.36 & 1.38 \\
\hline $1 / 1$ & 150 & 105 & 3 & 4.5 & - & 201.56 & 1.51 \\
\hline $7 / 5$ & 210 & 108 & 2 & 4.2 & - & 220.50 & 1.65 \\
\hline $7 / 5+\% 25$ sand & 210 & 108 & 2 & 4.2 & 37.5 & 235.03 & 1.71 \\
\hline $7 / 5+\% 50$ sand & 210 & 108 & 2 & 4.2 & 75 & 249.57 & 1.76 \\
\hline Density $\left(\mathrm{gr} / \mathrm{cm}^{3}\right)$ & 3.05 & 1 & & 2.55 & 2.58 & & \\
\hline
\end{tabular}

\section{Chemical additives}

Chemical thinners and hardening accelerator were used in grouting. As the permeability of the mica schist and calc-schist is low, it was anticipated that in case there is water absorption but no slurry absorption, additives like sodium sulphate at the rate of 0.5 to $1 \%$ weight of cement or commercial brand, L-10 Melment at the rate of 1 to $2 \%$ would be used. However, no such circumstance had been encountered in the application. Though there was no such need, if required, $\mathrm{NaSiO}_{3}$ in the slurries and $\mathrm{CaCl}_{2}$ in the sandy mixtures were planned to be used.

\section{Mixtures used in grouting applications}

The mortar mixtures, used in the grouting applications of Cindere dam and HEPP, are presented in Table 2. The bentonite was added to be mixture in the form of $10 \%$ bentonite solution.

\section{GROUT CURTAINS}

The drilling pattern and hole depths of curtain grouts were determined by evaluating the geotechnical circumstances. The ano cast length in the application project was taken as $24 \mathrm{~m}$. Nonetheless, when required by the geological circumstances and general work program of the site, the ano lengths were taken as 12 or $13 \mathrm{~m}$ in case of a decrease in the span and sparse cracks.

The holes of grout curtains were designed as upflow, $15^{\circ}$ inclined from the vertical axis, and perpendicular to the gallery axis the plan.

The grouting pressures that are recommended to be implemented in the grout curtain applications are given as follows (DSi, 1993; Özkan, 2006):

$\mathrm{Pt}=0.33 \mathrm{H}$ (In the last $2.5 \mathrm{~m}$ phase, this pressure value was recommended as $\mathrm{PT}=0.23 \mathrm{H}$ ).

Herein: Pt: Total effective pressure $(\mathrm{kg} / \mathrm{cm} 2)$. H: Distance from the midpoint of level, in which grouting is applied, to the hole mouth $(\mathrm{m})$.

In converting the effective pressure into the pressure to be read in manometer, correlation of following equation was used (DSi, 1993; Şekercioğlu, 2007):
$P_{m}=P_{T}+W * \frac{L}{10} * \cos \alpha$

In this equation: $\mathrm{W}$ = specific gravity of grouting slurry, $\mathrm{L}$ $=$ vertical distance between the mid-level and manometer, $\alpha=$ the angle between the well and the vertical.

The grout curtain holes were completely drilled from top to bottom; and grouting was implemented with the bottom to top levels method.

For the grout holes, the values for the last two levels were taken as $2.5 \mathrm{~m}$ whereas the other level heights were taken as $5.0 \mathrm{~m}$. Nevertheless, when required by the geological circumstances, the values belonging to the 5.0 $\mathrm{m}$ levels were decreased, according to the crack and fracture condition, with the approval of the management; or grouting was implemented by using from top to bottom levels method.

If a collapse occurred in the hole during drilling or the turnover (recirculation) water leaked $70 \%$, or more, after grouting and setting of the level, the grouting applications were finished by bottom to top levels method (Figure 1).

The grouting was initiated by using a grout with a weight ratio of cement/water $=1 / 3$. If the manometer pressure does not increase even if the mixture ratios and amounts presented in Table 3 were used, then the next mixture was to be used. If the manometer pressure increases during the grouting applications, by using both cement slurry and mortared mix in any ratio, the mixture was continued to be pumped until refusal is reached in the holes.

If the desired pressure is reached in both cement slurry and mortared mixtures and the level does not absorb slurry or mortar, then mixture with the ratio of $1 / 3$ would be used; and this mixture would be used for $20 \mathrm{~min}$. Nonetheless, refusal is accepted to be reached when 0.6 $\mathrm{It} / \mathrm{m}$.min or less slurry is absorbed in the $20 \mathrm{~min}$ time period. This amount was determined to be $60 \mathrm{lt}$ for $5 \mathrm{~m}$ level. The grouting procedure belonging to the following level or some other hole was later initiated.

Following the accomplishment of curtain drill construction or the construction of several ano casts, 


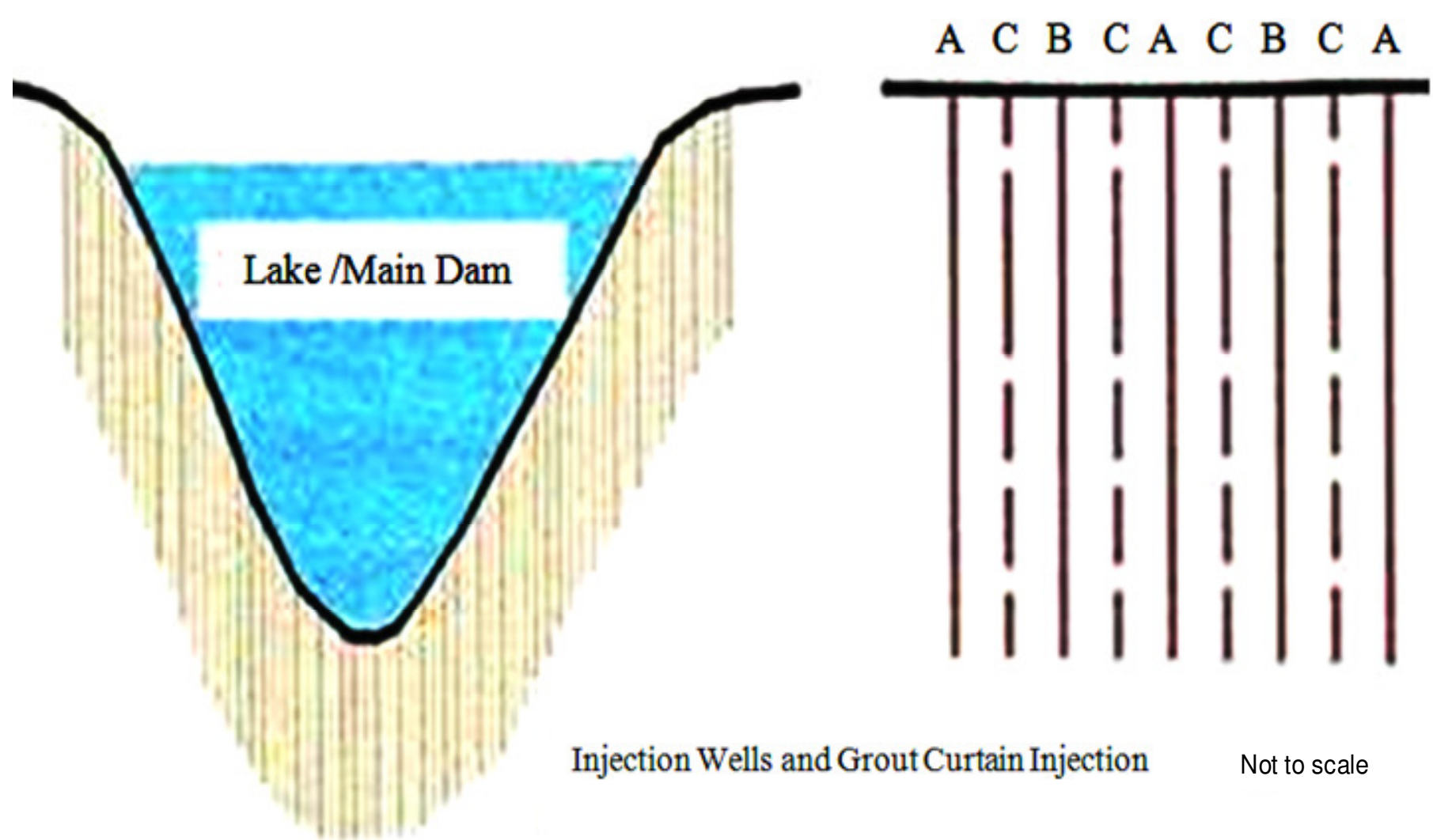

Figure 1. Curtain grouting.

Table 3. Mixture ratios used in the grout curtain applications in Cindere dam.

\begin{tabular}{ccc}
\hline Mixture ratio (cement/water) & Mixer number laid (1 mixer) & $\begin{array}{c}\text { Mixture ratio to use in case of manometer } \\
\text { pressure rise (cement/water) }\end{array}$ \\
\hline $1 / 3$ & 4 & $2 / 3$ \\
$2 / 3$ & 4 & $1 / 1$ \\
$1 / 1$ & 4 & $7 / 5$ \\
$7 / 5$ & 20 & $7 / 5+25 \%$ sand \\
$7 / 5+25 \%$ sand & 20 & $7 / 5+50 \%$ sand \\
$7 / 5+50 \%$ sand & 20 & $7 / 5+50 \%$ sand \\
\hline
\end{tabular}

perpendicular or inclined control holes were abridged, 2 in each ano $(24 \mathrm{~m})$, so that it would be located inside the drills with most water intake.

The length of the control holes were equivalent to the curtain holes in the region where it is bored; and hydraulic pressure tests were implemented, under the pressure value equal to the grouting pressure, in the all levels. During the hydraulic pressure tests, if the provision presented earlier could not be ensured in one or more levels, additional grouting was implemented by intervening in the section of the ano represented by the control hole or holes. Pressure values belonging to the hydraulic pressure test results implemented on ano head core drills, and control drills for grout curtain and grout curtain connection procedures are presented in Table 4.

\section{Grout curtain connection}

The grout curtains were implemented in the grouting galleries and derivation tunnels of the project.

The drilling and grouting methods and parameters applied in grout curtain connections have the same characteristics as the methods implemented in curtain grouts. All characteristics and formulas defined for grout curtains are valid for grout curtain connections. Nonetheless, differing from the grout curtains, the refusal pressure value implemented in grout curtain connection 
Table 4. WPT pressure values for ano head explanatory drills and control drills.

\begin{tabular}{ccc}
\hline Layer $(\mathbf{m})$ & Pressures applied $\left.\mathbf{( k g} / \mathbf{c m}^{2}\right)(\mathbf{R H})$ & Applied pressured $\left.\mathbf{( k g} / \mathbf{c m}^{2}\right)(\mathbf{C H})$ \\
\hline $0-5$ & $0.5-1-0.5$ & $0.5-1-0.5$ \\
$5-10$ & $1-2-1$ & $1-2-1$ \\
$10-15$ & $2-3-4-3-2$ & $2-3-4-3-2$ \\
$15-20$ & $2-4-6-4-2$ & $2-4-6-4-2$ \\
$20-25$ & $2-4-6-4-2$ & $2-4-6-7.5-6-4-2$ \\
$25-30$ & $2-4-6-8-6-4-2$ & $2-4-6-9-6-4-2$ \\
$30-35$ & $2-4-6-8-10-8-6-4-2$ & $2-4-6-8-11-8-6-4-2$ \\
$35-40$ & $2-4-6-8-10-8-6-4-2$ & $2-4-6-8-12-8-6-4-2$ \\
$40-45$ & $2-4-6-8-10-8-6-4-2$ & $2-4-6-8-14-8-6-4-2$ \\
$45-50$ & $2-4-6-8-10-8-6-4-2$ & $2-4-6-8-16-8-6-4-2$ \\
$50-55$ & $2-4-6-8-10-8-6-4-2$ & $2-4-6-8-17-8-6-4-2$ \\
$55-60$ & $2-4-6-8-10-8-6-4-2$ & $2-4-6-8-19-8-6-4-2$ \\
$60-65$ & $2-4-6-8-10-8-6-4-2$ & $2-4-6-8-21-8-6-4-2$ \\
$65-70$ & $2-4-6-8-10-8-6-4-2$ & $2-4-6-8-22-8-6-4-2$ \\
$70-75$ & $2-4-6-8-10-8-6-4-2$ & $2-4-6-8-24-8-6-4-2$ \\
$75-80$ & $2-4-6-8-10-8-6-4-2$ & $2-4-6-8-26-8-6-4-2$ \\
$80-85$ & $2-4-6-8-10-8-6-4-2$ & $2-4-6-8-27-8-6-4-2$ \\
\hline
\end{tabular}

applications was $3 \mathrm{~kg} / \mathrm{cm}^{2}$.

\section{Contact and consolidation grouting}

Contact and consolidation grouting applications were designed to be in the grouting gallery, positioned at the right coast at the level of $272.00 \mathrm{~m}$, and in the transportation gallery at the level of $220.50 \mathrm{~m}$ in the left coast.

\section{Contact grouting}

For the contact grouting, the drilling length concrete thickness value became $+50 \mathrm{~cm}$. Consolidation grouting for the anos were not initiated unless contact groutings of at least two anos were finished.

The consolidation grouting was applied by using the same holes in which contact grouting was implemented.

The consolidation grouting drill length was calculated as $5.50 \mathrm{~m}$ (Tunnel diameter $+2.00 \mathrm{~m}$ ). 4 drills, zigzagged in every $3 \mathrm{~m}$ and having $45^{\circ}$ inclination with each other, were implemented in each section (Figures 2 to 3 ). 3.00 $\mathrm{m}$ spacing between the sections of was decreased to $2.50 \mathrm{~m}$ in regions, where they coincide with PVC water holders inside concrete coating ano joints.

The effective pressure value implemented inside the contact grouting holes was $\mathrm{Pt}=2 \mathrm{~kg} / \mathrm{cm} 2$. Nonetheless, since the purpose is to fill the spacing between concrete and soil in the contact grouting, the grout pressure, with the length equal to the vertical distance between the contact point of hole and manometer, was added for the holes above the manometer while the value was subtracted for the holes below the manometer; and the manometer pressure value was found accordingly.

The ano cast dimension in the contact groutings was taken as $12 \mathrm{~m}$. If required, grouting was applied according to the decreasing space method in the anos. Starting first from the holes below the galleries, grouting was applied in the lower half side drills, after one row is formed, then in the upper half side drills, and lastly in the ceiling holes.

In the contact grouting sections, it is required that concrete coating was poured at least 21 days before.

Starting from the holes in the lower half of gallery, slurry with $1 / 3$ ratio was used; and if no increase in the manometer value was observed although 4 mixers of slurry was presented, 4 mixers of slurry, having $2 / 3$ lawn/water ratio, 4 mixers of $1 / 1$ slurry, 20 mixers $7 / 5$ slurry were, respectively, presented; and if there was still no increase in the value, 25 to $50 \%$ (in relation with the cement amount) sandy mixtures were used in the procedure.

In the upper half, however, starting from 4 mixers $1 / 1$ slurry was used; if no increase was observed in the manometer, then it was continued with 20 mixers of $7 / 5$ mixture. If still no increase was observed in the manometer, 25 to 50\% sandy mixtures were used. 50\% mixture was valid after using the 20 mixers of $25 \%$ mixture; if an increase is observed in the manometer, refusal was ensured with that mixture.

If the desired pressure value is reached in both cement and mortared mixtures and the level does not absorb slurry or mortar in a period of $10 \mathrm{~min}$, the mixture with $1 / 3$ cement/water ratio would be used; and the grouting 


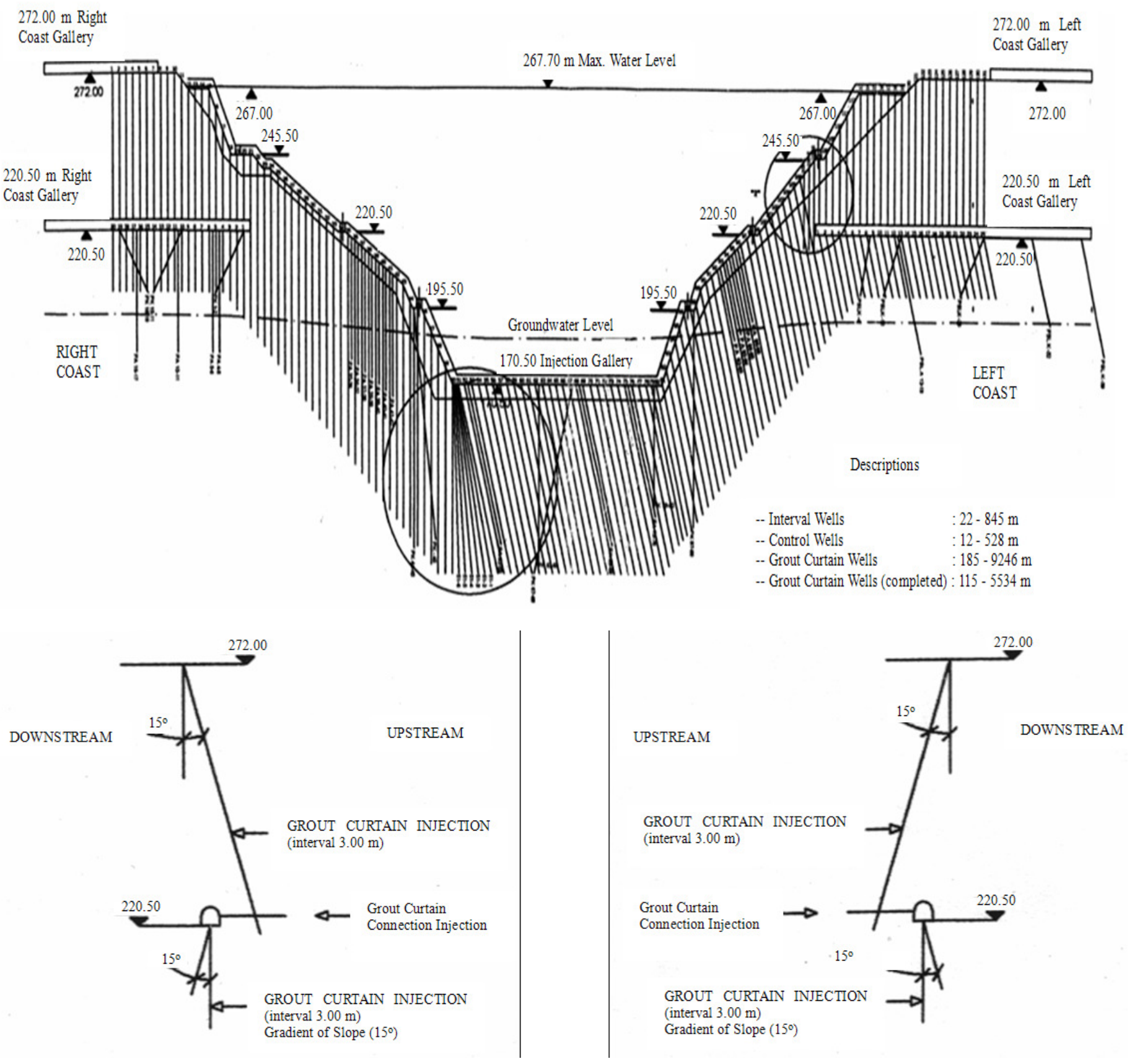

Figure 2. Applicable cross-section of grout curtain and upstream-downstream grouting section in Cindere dam.

procedure would be continued for $20 \mathrm{~min}$. Nonetheless, it is projected that, when $0.6 \mathrm{It} / \mathrm{m} . \mathrm{min}$ or less slurry is absorbed in the 20 min time period, the refusal would be accepted as reached and the grouting of another hole would be initiated.

\section{Consolidation groutings}

The drill lengths of consolidation groutings were observed to be $5.50 \mathrm{~m}$ after the tunnel concrete in each side. Accordingly, the ano casts were taken as $24 \mathrm{~m}$ for the consolidation groutings.

The consolidation drill was implemented by using the holes previously used in contact groutings. In the drills with the total length of $5.50 \mathrm{~m}$, grouting was applied in the levels of $2.50+3.00 \mathrm{~m}$. In the consolidation drills, if required, chemical diluents can be used when there is no parallelism between the results of the hydraulic test, implemented prior to groutings, and slurry intake of the 


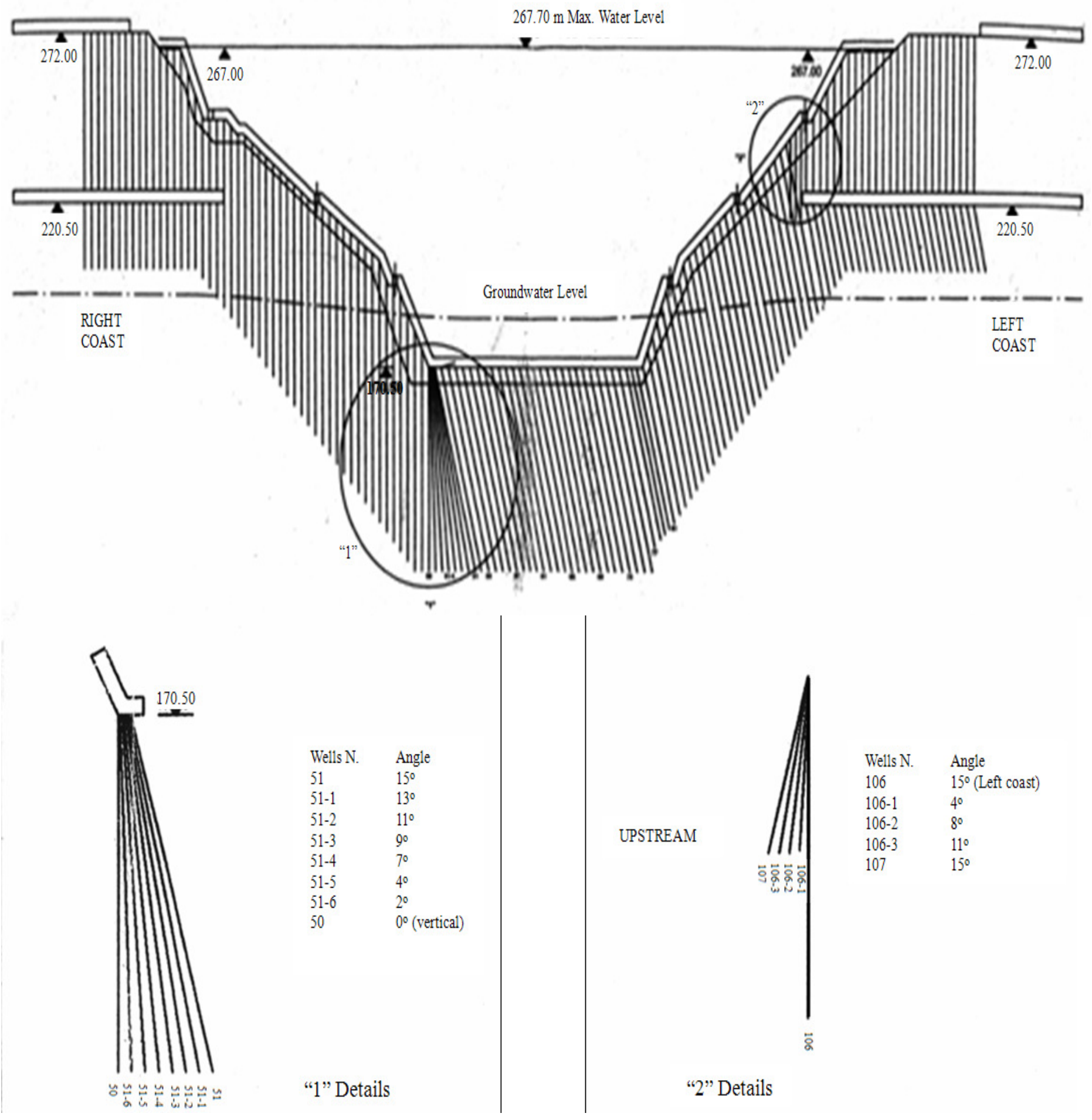

Figure 3. Applicable cross-section of grout curtain, drill numbers, and grouting angle details in Cindere dam.

formation. Consequently, the diluent material was used, with the ratio of 0.5 to $1 \%$ cement amount according to the water temperature, in $1 / 1$ and denser mixtures.

In the sandy mixtures, however, $3 \% \mathrm{CaCl}_{2}$ was used.
The cement with a high specific surface value was definitely used in the sections where water leakage exists but the slurry intake ratio is lesser than $1 / 3$.

In the groutings, 4 mixers of $1 / 3$ slurry was used; if no 
increase in the manometer value was observed, 4 mixers of $2 / 3$ slurry was to be used. If there was still no increase in the value, 4 mixers of $1 / 1$ slurry, 20 mixers of $7 / 5$ slurry would, respectively, be presented to the mxiture. If no increase was observed in the manometer, then sandy mixtures would be used continuously until refusal is observed.

The effective pressure applied on the consolidation holes was $\mathrm{Pt}=2+0.33 \mathrm{H} \mathrm{kg} / \mathrm{cm}^{2}$. The ending decision of the grouting procedure of a hole and level, in relation with the upwards or downwards drilling direction of the hole in the manometer, was decided by adding or subtracting the hydrostatic pressure of slurry to/from the grouting pressure.

Following the end of consolidation grouting in several anos or the complete finishing of entire tunnel, the control drills were abridged in number and locations decided by the management ( 2 to 3 at the points with the most intake in $24 \mathrm{~m}$ ano). The control drills could be with or without core but always related with the hydraulics. Nevertheless, the control drills, if only hydraulic pressure test and application without cores is required, were abridged as 46 or $56 \mathrm{~mm}$ diameter in size.

As result of the test, the refusal was accepted to be enabled if 3 Lugeons or lesser amount of water leaked. Nonetheless, additional grouting was applied if the water leakage was more in amount than 3 Lugeons. During the consolidation groutings, when the slurry does not leak from the hole and the desired pressure is reached, it is provided that the slurry would be added for $10 \mathrm{~min}$. If the level intakes $0.6 \mathrm{lt} / \mathrm{m} / \mathrm{min}$ and lesser amount of slurry, the refusal is then accepted to be enabled. This amount corresponds to $36 \mathrm{~L}$ for $10 \mathrm{~min}$.

\section{DISCUSSION AND CONCLUSION}

The grout curtain grouting was implemented on the bedrock through the dam embankment in Cindere Dam construction. In this study, the materials used in the grouting, which was implemented by using applied research method in relation with the control of the work, and the materials contained in the grout mortar were investigated by observations in the site. It was detected that the validity and values of the application was under the limits advised by DSI.
It was concluded that the mixture ratios, advised by DSI, and the code of practice were compatible with the geological structure examined within this study. Based on this data, no water leakage from the bedrock is expected, through the dam axis, when the dam starts to hold water. It is aimed, with the research conducted, to set an example for the future studies with soil rehabilitation, grouting, and permeability purposes.

\section{ACKNOWLEDGEMENTS}

The authors would like to offer their gratitude to General Directorate of State Hydraulic Works Directorate (DSI) for presenting information.

\section{REFERENCES}

Anonymous (1979). Classification of Rocks and Soils for Engineering Geological Mapping. Part 1 Rock and Soil Materials Bull. Int. Ass. Eng. Geol., 19: 364-371.

ASTM (1980). Standard Method of Test for Unconfined Compressive Strength of Rock Specimens. Ann. Book ASTM Standards, 19: 440443.

Batı Söke Çimento TAŞ (2002). Cement Test Report. İzmir, p. 201.

Bieniawski ZT (1989). Engineering Rock Mass Classifications. John Wiley \& Sons, New York.

DSI (1999). General Directorate of State Hydraulic Works, Cindere dam and HEPP Application Projects. Aydın.

DSI (1993). General Directorate of State Hydraulic Works. Boring and Grout Technical Specifications. Ankara.

Karakaya Bentonite (2002). Laboratory results. Ankara.

Kutzner C (1996). Grouting of Rock and Soil. Rotterdam AA. Balkema, p. 271.

Özkan H (2006). Injection Methods and Applications. Ankara, p. 219.

Turkish Standards TS 707 (1980). Method for Sampling of Aggregates for Concrete Reducing Samples to Testing Size. Turkish Standards Institutions, Ankara.

Turkish Standards TS EN 196-1 (2002). Methods of Testing Cement Part 1: Determination of Strength. Ankara.

Turkish Standards (TS) 197-1 (2002). Compositions and Conformity Criteria for Command Cements. UDK 669.94. Turkish Standards Institutions, Ankara.

Turkish Standards TS 977 / UDK 622.36 (1971). Bentonite Drilling Mud Additive, Turkish Standards Institute, Ankara.

Turkish Standards TS 10157 (1992). Sulphate-Resisting Cement. Turkish Standards Institutions, Ankara.

Tosun H (2000). Turkey Screen Design Principles and Practice of Injection Fill Dams. 8th Congress on Soil mechanics and Foundation Engineering, İstanbul. 